STRUCTURAL BIOLOGY COMMUNICATIONS

ISSN 2053-230X

\section{Cloning, expression, purification, crystallization and X-ray crystallographic analysis of recombinant human C1ORF123 protein}

\author{
Siti Nurulnabila A. Rahaman, ${ }^{a}$ Jastina Mat Yusop, ${ }^{a}$ Zeti-Azura Mohamed- \\ Hussein, ${ }^{\mathrm{a}, \mathrm{b}}$ Kok Lian Ho, ${ }^{\mathrm{c}}$ Aik-Hong Teh, ${ }^{\mathrm{d}}$ Jitka Waterman ${ }^{\mathrm{e}}$ and Chyan Leong $\mathrm{Ng}^{\mathrm{a} *}$
}

Received 2 December 2015

Accepted 2 February 2016

Edited by R. Sankaranarayanan, Centre for Cellular and Molecular Biology, Hyderabad, India

Keywords: C1ORF123; hypothetical protein; DUF866; polycystic ovary syndrome; bioinformatic analysis.

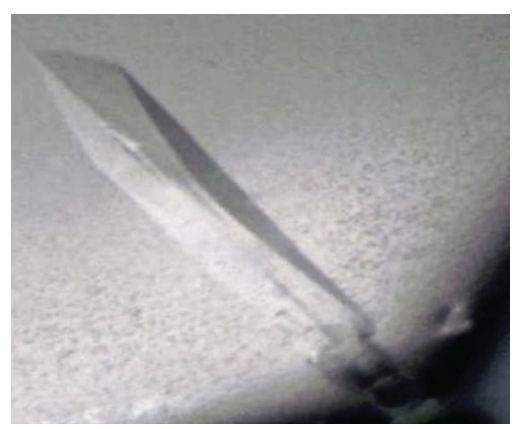

anstitute of Systems Biology, Universiti Kebangsaan Malaysia, 43600 UKM Bangi, Selangor, Malaysia, 'bSchool of
Biosciences and Biotechnology, Faculty of Science and Technology, Universiti Kebangsaan Malaysia, 43600 UKM Bangi,
Selangor, Malaysia, ' Department of Pathology, Faculty of Medicine and Health Sciences, Universiti Putra Malaysia,
43400 UPM Serdang, Selangor, Malaysia, 'dCentre for Chemical Biology, Universiti Sains Malaysia, 11900 Bayan Lepas,
Penang, Malaysia, and ${ }^{\mathbf{e}}$ Diamond Light Source, Harwell Science and Innovation Campus, Didcot OX11 0DE, England.
${ }^{*}$ Correspondence e-mail: clng@ukm.edu.my

C1ORF123 is a human hypothetical protein found in open reading frame 123 of chromosome 1 . The protein belongs to the DUF866 protein family comprising eukaryote-conserved proteins with unknown function. Recent proteomic and bioinformatic analyses identified the presence of C1ORF123 in brain, frontal cortex and synapses, as well as its involvement in endocrine function and polycystic ovary syndrome (PCOS), indicating the importance of its biological role. In order to provide a better understanding of the biological function of the human C1ORF123 protein, the characterization and analysis of recombinant C1ORF123 (rC1ORF123), including overexpression and purification, verification by mass spectrometry and a Western blot using anti-C1ORF123 antibodies, crystallization and X-ray diffraction analysis of the protein crystals, are reported here. The rC1ORF123 protein was crystallized by the hanging-drop vapordiffusion method with a reservoir solution comprised of 20\% PEG 3350, 0.2 M magnesium chloride hexahydrate, $0.1 M$ sodium citrate $\mathrm{pH}$ 6.5. The crystals diffracted to $1.9 \AA$ resolution and belonged to an orthorhombic space group with unit-cell parameters $a=59.32, b=65.35, c=95.05 \AA$. The calculated Matthews coefficient $\left(V_{\mathrm{M}}\right)$ value of $2.27 \AA^{3} \mathrm{Da}^{-1}$ suggests that there are two molecules per asymmetric unit, with an estimated solvent content of $45.7 \%$.

\section{Introduction}

Open reading frame 123 , which is located in the short arm of human chromosome 1, encodes a hypothetical protein known as C1ORF123 (Selvarajan \& Shanmughavel, 2014). C1ORF123 consists of 160 amino acids with a calculated molecular weight of approximately $18 \mathrm{kDa}$. The C1ORF123 protein is exclusively found in eukaryotic cells and belongs to the DUF866 family of proteins of unknown function. To date, the only known protein structure from the DUF866 family is that of the Plasmodium falciparum homologue MAL13P1.257, which shares $26 \%$ sequence identity with C1ORF123 (Holmes et al., 2006). No functional studies have yet been reported for MAL13P1.257.

In humans, C1ORF123 is expressed in various anatomical regions, including the brain, skeletal muscles and ovary. Bioinformatics analysis has annotated the C1ORF123 protein as a cellular protein (Selvarajan \& Shanmughavel, 2014) and suggests that it is involved in the pathway related to an 
Table 1

Identified interacting partners of C1ORF123 and its homologues from the STRING database (version 9.1).

\begin{tabular}{|c|c|c|c|c|}
\hline No. & Protein & Description & Experimental evidence & Reference \\
\hline 1 & RHBDL1 & Rhomboid, veinlet-like 1 & Two-hybrid pooling assay & Giot et al. (2003) \\
\hline 2 & TMBIM6 & $\begin{array}{l}\text { Transmembrane BAX inhibitor motif-containing protein } 6 \text {; } \\
\text { suppressor of apoptosis }\end{array}$ & Two-hybrid pooling assay & Giot et al. (2003) \\
\hline 3 & CDKN1A & Cyclin-dependent kinase inhibitor $1 \mathrm{~A}$; cell-cycle regulator & Two-hybrid pooling assay & Stelzl et al. (2005) \\
\hline 4 & SRP14 & Signal recognition particle $14 \mathrm{kDa}$ & Tandem affinity assay & Krogan et al. (2006) \\
\hline 5 & SRP19 & Signal recognition particle $19 \mathrm{kDa}$ & Tandem affinity assay & Krogan et al. (2006) \\
\hline 6 & NPUK68 & $\begin{array}{l}\text { UKp68-like protein; binds polyadenosine RNA } \\
\text { oligonucleotides }\end{array}$ & Affinity capture-RNA assay & Batisse et al. (2009) \\
\hline 7 & $\mathrm{ZC} 3 \mathrm{H} 14$ & $\begin{array}{l}\text { Zinc-finger } \mathrm{CCCH} \text { domain-containing protein } 14 \text {; binds } \\
\text { polyadenosine RNA oligonucleotides }\end{array}$ & Affinity capture-RNA assay & Batisse et al. (2009) \\
\hline 8 & ANXA1 & $\begin{array}{l}\text { Annexin } 1 \text {; calcium/phospholipid-binding protein which } \\
\text { promotes membrane fusion and is involved in exocytosis; } \\
\text { also regulates phospholipase } \mathrm{A}_{2} \text { activity }\end{array}$ & Two-hybrid assay & Vinayagam et al. (2011) \\
\hline 9 & UBB & $\begin{array}{l}\text { Ubiquitin B; protein degradation, maintenance of chromatin } \\
\text { structure, regulation of gene expression, stress response, } \\
\text { ribosome biogenesis and DNA repair }\end{array}$ & Affinity capture-MS assay & Danielsen et al. (2011) \\
\hline 1. & $\mathrm{UBC}$ & $\begin{array}{l}\text { Ubiquitin C; protein degradation, maintenance of chromatin } \\
\text { structure, regulation of gene expression, stress response, } \\
\text { ribosome biogenesis and DNA repair }\end{array}$ & Affinity capture-MS assay & Danielsen et al. (2011) \\
\hline 11 & $\begin{array}{l}\text { LARP1 and } \\
\text { LARP1B }\end{array}$ & La ribonucleoprotein domain family & Affinity capture-RNA assay & Schenk et al. (2012) \\
\hline 12 & SSB & $\begin{array}{l}\text { Sjögren syndrome antigen B (autoantigen La); binds to the } 3^{\prime} \\
\text { poly }(\mathrm{U}) \text { termini of nascent RNA polymerase III transcripts }\end{array}$ & Affinity capture-RNA assay & Schenk et al. (2012) \\
\hline
\end{tabular}

Table 2

Macromolecule-production information.

\begin{tabular}{ll}
\hline Source organism & H. sapiens \\
DNA source & Chemically synthesized (GenScript, USA) \\
Cloning vector & pUC57 \\
Expression vector & pET-28b \\
Expression host & E. coli strain BL21 Rosetta-gami (DE3) \\
Complete amino-acid sequence & MGSSHHHHHSSGLVPRSHMGKIALQLKATLEN- \\
\cline { 2 - 2 } of the construct $\dagger$ & ITNLRPVGEDFRWYLKMKCGNCGEISDKWQYI- \\
& RLMDSVALKGGRGSASMVQKCLCARENSIEIL- \\
& SSIKPYNAEDNENFKTIVEFECRGLEPVDFQP- \\
& QAGFAVESGTAFSDINLQEKDWTDYDEKAQES- \\
& VGIYEVTHQFVKC
\end{tabular}

abnormality known as polycystic ovary syndrome (PCOS; Mohamed-Hussein \& Harun, 2009). PCOS is a heterogeneous endocrine disorder that causes $\sim 10 \%$ of infertility in women (Diamanti-Kandarakis, 2008). Interestingly, a proteomic analysis of goat adipose tissue also identified the C1ORF123 homologue as one of the adipokines that may be involved in endocrine function (Restelli et al., 2014). Other proteomics studies have found that the C1ORF123 protein is largely expressed in the hippocampus of people suffering from schizophrenia, bipolar disorder and methamphetamine-induced sensitization of the prefrontal cortex, as well as being a unique protein in the frontal cortex of aged rats associated with slowwave sleep (SWS) (Schubert et al., 2015; Wearne et al., 2015; Vazquez et al., 2009). This indicates the involvement of C1ORF123 in psychotic diseases or in age-related changes in brain function. A homologue of C1ORF123 has also been identified in the electric organ of the pacific electric ray Torpedo californica along with many neuromuscular junctions and presynaptic proteins, suggesting its role in synapse structure and maintenance (Mate et al., 2011). C1ORF123 has also been identified as an O-GlcNAc transferase (OGT) interactor, indicating its possible role in the post-translational $\mathrm{O}$ GlcNAcylation of proteins, which is important in many biological processes (Deng et al., 2014). The network-based approach of the STRING database (Franceschini et al., 2013) further deciphers the potential function of C1ORF123 and its homologues by the identification of interacting partners (Table 1). To better understand its biological function, we are working towards structural analysis of the human C1ORF123 protein. Here, we report the cloning, overexpression, purification, protein characterization and crystallization together with the initial X-ray crystallographic analysis of recombinant C1ORF123 (rC1ORF123).

\section{Materials and methods}

\subsection{Protein production}

The 492 bp coding sequence for human C1ORF123 (Gene ID 54987) was synthesized and cloned between the NdeI and HindIII restriction-endonuclease sites of the pUC57 cloning vector (GenScript, USA). The C1ORF123 gene was subcloned into the pET-28b vector using the same restriction enzymes to produce the pET-28b-C1ORF123 construct, which includes a $6 \times$ His fusion tag at the $\mathrm{N}$-terminus of the recombinant protein. The calculated molecular weight of rC1ORF123, which contains 20 amino acids as a fusion tag at the N-terminus (Table 2), is approximately $20 \mathrm{kDa}$ using ProtParam (Gasteiger et al., 2005). Subsequently, the pET-28bC1ORF123 construct was transformed into Escherichia coli strain BL21 Rosetta-gami (DE3) cells. A single colony of transformant was inoculated into $6 \mathrm{ml}$ Luria-Bertani (LB) broth containing $50 \mathrm{mg} \mathrm{ml}^{-1}$ kanamycin and agitated 
overnight in an incubator shaker at $250 \mathrm{rev} \mathrm{min}^{-1}$ and $310 \mathrm{~K}$. The bacterial culture was then inoculated into $11 \mathrm{LB}$ broth supplemented with $50 \mathrm{mg} \mathrm{ml}^{-1}$ kanamycin and grown at $250 \mathrm{rev} \min ^{-1}$ at $310 \mathrm{~K}$. After the $\mathrm{OD}_{600}$ had reached 0.5-0.6, expression of the recombinant protein was induced by adding $1 \mathrm{~m} M$ isopropyl $\beta$-D-1-thiogalactopyranoside (IPTG). The culture was grown for a further $3-4 \mathrm{~h}$ at $310 \mathrm{~K}$ before the cells were harvested by centrifugation at $17968 \mathrm{~g}$.

The bacterial pellet was resuspended in lysis buffer $(10 \mathrm{ml}$ per gram of cell pellet) consisting of $25 \mathrm{~m} M$ Tris- $\mathrm{HCl} \mathrm{pH} 7.5$, $100 \mathrm{~m} M \mathrm{NaCl}, 20 \mathrm{~m} M \beta$-mercaptoethanol, $20 \mathrm{~m} M$ imidazole before being lysed by sonication (Qsonica, 30 cycles of $38 \%$ amplitude for $30 \mathrm{~s}$ each). The cell lysate was centrifuged at $17968 \mathrm{~g}$ at $277 \mathrm{~K}$ for $30 \mathrm{~min}$ to separate the soluble proteins from the cell debris. The supernatant was filter-sterilized with a $0.22 \mu \mathrm{m}$ PVDF membrane filter before loading it onto an Ni-NTA-coupled HisTrap HP $5 \mathrm{ml}$ column (GE Healthcare) which had been pre-equilibrated with binding buffer consisting of $25 \mathrm{~m} M$ Tris- $\mathrm{HCl} \mathrm{pH}$ 7.5, $100 \mathrm{mM} \mathrm{NaCl}, 20 \mathrm{~m} M$ $\beta$-mercaptoethanol, $50 \mathrm{mM}$ imidazole. The rC1ORF123 protein was eluted using a linear gradient of washing buffer

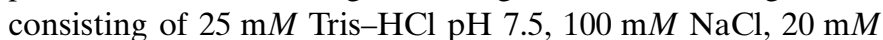
$\beta$-mercaptoethanol, $500 \mathrm{~m} M$ imidazole. The protein eluted at an imidazole concentration of $79 \mathrm{~m} M$. Fractions containing the $\mathrm{rC1ORF} 123$ protein were pooled and concentrated using Vivaspin concentrators fitted with a $3 \mathrm{kDa}$ molecular-weight cutoff filter (Sartorius, Germany). The concentrated rC1ORF123 protein was further purified by size-exclusion chromatography (SEC) using a HiLoad 16/600 Superdex 75 pg gel-filtration column (GE Healthcare, USA) pre-equilibrated with size-exclusion buffer consisting of $25 \mathrm{~m} M$ Tris- $\mathrm{HCl} \mathrm{pH}$ $7.5,100 \mathrm{~m} M \mathrm{NaCl}, 20 \mathrm{~m} M \beta$-mercaptoethanol. The purity of the rC1ORF123 protein was verified using $12 \%$ SDS-PAGE (Fig. 1). The protein concentration of rC1ORF123 was assessed using the Bradford assay (Bio-Rad, USA). Fractions containing the rC1ORF123 protein purified by size-exclusion chromatography were also pooled and concentrated to $8.0 \mathrm{mg} \mathrm{ml}^{-1}$.

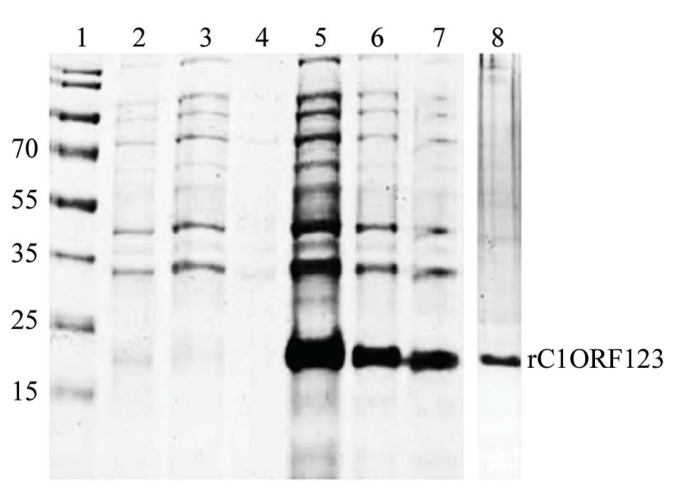

(a)

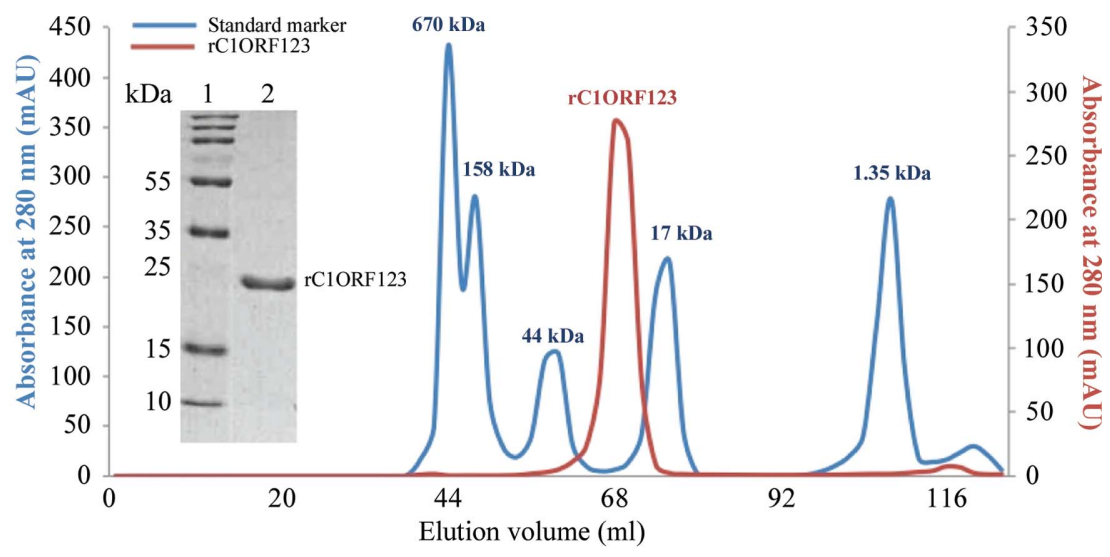

(b)

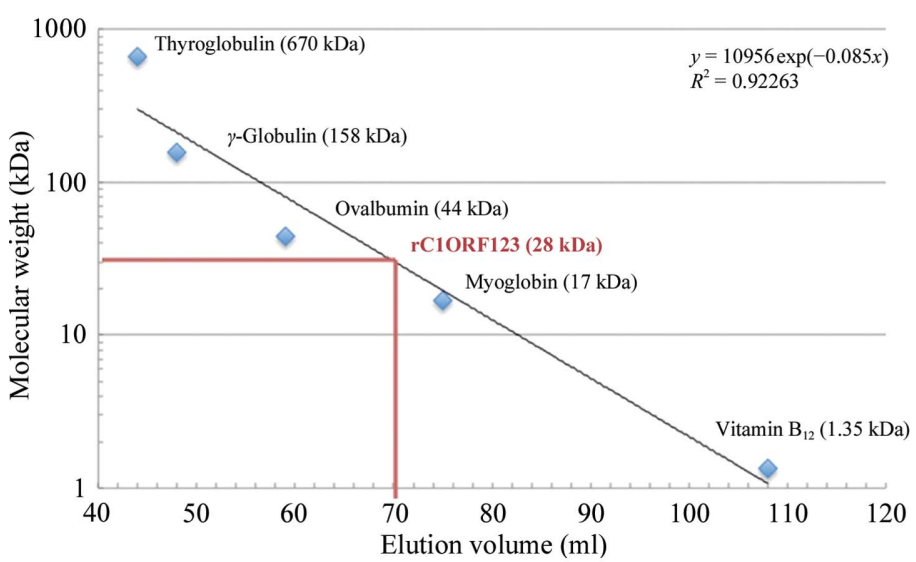

(c)

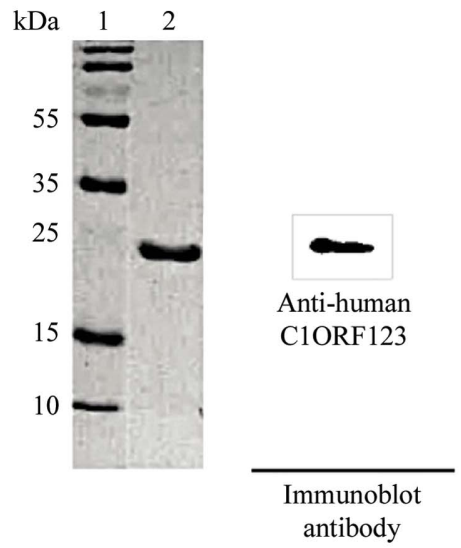

(d)

Figure 1

Overexpression, purification and identification using a Western blot of recombinant C1ORF123 protein. (a) Analysis of the overexpressed and $\mathrm{Ni}^{2+}$ NTA affinity-purified rC1ORF123 protein using SDS-PAGE (12\%). Lane 1, PageRuler prestained protein ladder (Thermo Scientific, USA; labelled in $\mathrm{kDa}$ ); lanes 2, 3 and 4, total protein, pellet and supernatant of crude extract before IPTG induction, respectively, as a negative control; lanes 5, 6 and 7, total protein, pellet and supernatant of crude extract after IPTG induction, respectively; lane 8, rC1ORF123 purified using $\mathrm{Ni}^{2+}-\mathrm{NTA}$ affinity chromatography. (b) Size-exclusion chromatography (SEC) results using a HiLoad 16/600 Superdex 75 pg gel-filtration column (GE Healthcare, UK). The rC1ORF123 protein eluted as a single peak between those for myoglobin (17 kDa) and ovalbumin (44 kDa), suggesting that the rC1ORF123 protein may be a monomer in solution. rC1ORF123 purified by SEC is shown on $12 \%$ SDS-PAGE, with the protein band corresponding to $~ 20 \mathrm{kDa}$. (c) Calibration curve for size-exclusion chromatography on a Superdex 16/600 75 pg gel-filtration column indicating the molecular weight of rC1ORF123 to be $\sim 28 \mathrm{kDa}$. $(d)$ The recombinant rC1ORF123 protein was positively detected by a Western blot using anti-human C1ORF123 antibodies (right panel); the band at $\sim 20 \mathrm{kDa}$ corresponding to purified rC1ORF123 is shown (left panel). 
Table 3

Crystallization information.

\begin{tabular}{|c|c|}
\hline Method & $\begin{array}{l}\text { Sitting-drop vapor diffusion (initial } \\
\text { crystallization) and hanging-drop vapor } \\
\text { diffusion (crystal optimization) }\end{array}$ \\
\hline Plate type & $\begin{array}{l}\text { 96-well MRC plates (initial crystal screening) } \\
\text { and 24-well plates (crystal optimization) }\end{array}$ \\
\hline Temperature (K) & 293 \\
\hline $\begin{array}{l}\text { Protein concentration } \\
\left(\mathrm{mg} \mathrm{ml}^{-1}\right)\end{array}$ & 8.0 (initial screening) and 7.8 (optimization) \\
\hline $\begin{array}{l}\text { Buffer composition of } \\
\text { protein solution }\end{array}$ & $\begin{array}{l}25 \mathrm{~m} M \text { Tris-HCl, } 0.1 M \text { sodium chloride } \\
\text { tribasic pH 7.5, } 20 \mathrm{~m} M \beta \text {-mercapthoethanol }\end{array}$ \\
\hline $\begin{array}{l}\text { Composition of reservoir } \\
\text { solution }\end{array}$ & $\begin{array}{l}0.2 \mathrm{M} \text { magnesium chloride hexahydrate, } 0.1 \mathrm{M} \\
\text { sodium citrate tribasic buffer pH } 6.5,20 \% \\
\text { polyethylene glycol } 3350\end{array}$ \\
\hline Volume and ratio of drop & $\begin{array}{l}1 \mu \mathrm{l}, 1: 1 \text { ratio of protein:reservoir solution (initial } \\
\text { crystal screening); } 2 \mu \mathrm{l}, 1: 1 \text { ratio of protein: } \\
\text { reservoir solution (crystal optimization) }\end{array}$ \\
\hline Volume of reservoir & $\begin{array}{l}80 \mu \mathrm{l} \text { (initial crystallization) and } 1.0 \mathrm{ml} \text { (crystal } \\
\text { optimization) }\end{array}$ \\
\hline
\end{tabular}

\subsection{Verification of recombinant C1ORF123 protein using a} Western blot

A Western blot was performed according to the protocol described by Mahmood \& Yang (2012). rC1ORF123 proteins were run on a $12 \%$ SDS-PAGE gel and transferred to a nitrocellulose membrane. After blocking with bovine serum albumin (BSA) for $1 \mathrm{~h}$ at room temperature, the membrane was probed with rabbit anti-human C1ORF123 antibodies (Sigma-Aldrich) for $2 \mathrm{~h}$ at room temperature followed by two 10 min PBST washes with agitation. The membrane was then incubated at room temperature for $1 \mathrm{~h}$ with a goat anti-rabbit IgG secondary antibody conjugated to horseradish peroxidase (HRP) (Sigma-Aldrich). The membrane was washed twice with PBST for $10 \mathrm{~min}$ and then soaked in SuperSignal West Pico chemiluminescent substrate (Thermo Scientific) for $\sim 5$ min. The results were obtained using a chemiluminescent imaging system.

\subsection{Mass-spectrometry}

To confirm the sequence and the molecular weight of the expressed rC10RF123 protein, a single protein band with a molecular weight of approximately $20 \mathrm{kDa}$ was excised from the $12 \%$ SDS-PAGE gel (Fig. 1a) and used for protein identification by mass spectrometry. Peptides obtained after trypsin digestion of rC1ORF123 were extracted and analyzed by matrix-assisted laser desorption/ionization time-of-flight/ time-of-flight mass spectrometry (MALDI-TOF/TOF MS) using a 5800 Proteomics Analyzer mass spectrometer (Applied Biosystems/SCIEX; Bringans et al., 2008) by Proteomics International Pty Ltd (Australia). Protein identification was carried out using the Mascot sequence-matching software (Matrix Science) based on the Ludwig NR database.

\subsection{Crystallization}

The rC1ORF123 protein was purified to homogeneity in a buffer consisting of $25 \mathrm{~m} M$ Tris- $\mathrm{HCl} \mathrm{pH} 7.5,100 \mathrm{~m} M \mathrm{NaCl}$, $20 \mathrm{~m} M \beta$-mercaptoethanol. It was then concentrated to $8 \mathrm{mg} \mathrm{ml}^{-1}$ and used for initial crystallization screening with commercially available crystallization screening kits such as
Table 4

Data collection and processing.

Values in parentheses are for the outer shell.

\begin{tabular}{ll}
\hline Diffraction source & I02, Diamond Light Source \\
Wavelength $(\AA)$ & 0.9797 \\
Temperature $(\mathrm{K})$ & 100 \\
Detector & Pilatus $6 \mathrm{M}$ \\
Crystal-to-detector distance $(\mathrm{mm})$ & 340.75 \\
Rotation range per image $\left(^{\circ}\right)$ & 0.2 \\
Total rotation range $\left({ }^{\circ}\right)$ & 180 \\
Space group & $P 2_{1} 2_{1} 2$ or $P 2_{1} 2_{1} 2_{1}$ \\
$a, b, c(\AA)$ & $59.32,65.35,95.05$ \\
$\alpha, \beta, \gamma\left({ }^{\circ}\right)$ & $90,90,90$ \\
Mosaicity $\left({ }^{\circ}\right)$ & 0.86 \\
Resolution range $(\AA)$ & $30.90-1.90(1.94-1.90)$ \\
Total No. of reflections & 159233 \\
No. of unique reflections & 29180 \\
Completeness $(\%)$ & $98.1(97.2)$ \\
Multiplicity & $5.5(5.3)$ \\
$\langle I / \sigma(I)\rangle$ & $13.8(3.0)$ \\
$R_{\text {meas }} \dagger$ & $0.065(0.526)$ \\
Overall $B$ factor from Wilson plot $\left(\AA^{2}\right)$ & 35.3 \\
\hline
\end{tabular}

$\dagger R_{\text {meas }}=\sum_{h k l}\{N(h k l) /[N(h k l)-1]\}^{1 / 2} \sum_{i}\left|I_{i}(h k l)-\langle I(h k l)\rangle\right| / \sum_{h k l} \sum_{i} I_{i}(h k l)$, where $N(h k l)$ is the multiplicity of reflection $h k l$.

Index, Crystal Screen and Crystal Screen 2 (Hampton Research). Screening was performed using the sitting-drop vapor-diffusion method in standard 96-well MRC crystallization plates (Molecular Dimensions). Drops consisting of $0.5 \mu \mathrm{lC}$ rORF123 protein and $0.5 \mu \mathrm{l}$ reservoir solution were equilibrated against $80 \mu \mathrm{l}$ reservoir solution at $293 \mathrm{~K}$. Initial crystal hits were obtained from several crystallization conditions. The crystallization conditions were further optimized using the hanging-drop vapor-diffusion method in 24-well plates with crystallization drops consisting of $1 \mu$ protein solution (concentrated to $7.8 \mathrm{mg} \mathrm{ml}^{-1}$ ) and $1 \mu \mathrm{l}$ reservoir solution. Single crystals were obtained after $5 \mathrm{~d}$ from drops comprised of reservoir solution consisting of $0.2 \mathrm{M}$ magnesium chloride hexahydrate, $0.1 \mathrm{M}$ sodium citrate tribasic $\mathrm{pH} 6.5$, $20 \%$ PEG 3350. The best crystals, with typical dimensions of $\sim 400 \times 100 \times 50 \mu \mathrm{m}$ (Fig. $2 a$ ), were selected for X-ray diffraction analysis. The crystallization of $\mathrm{rC1ORF} 123$ is summarized in Table 3.

\subsection{Data collection and processing}

Prior to flash-cooling in liquid nitrogen, the rC1ORF123 crystals were immersed for $5 \mathrm{~min}$ at $293 \mathrm{~K}$ in cryoprotectant solution consisting of $0.1 \mathrm{M}$ sodium citrate buffer $\mathrm{pH} 6.5$, $0.2 M$ magnesium chloride tribasic, 22\% PEG 3350, 20\% glycerol. X-ray diffraction data were collected on the I02 beamline at Diamond Light Source, UK at $100 \mathrm{~K}$ in a nitrogen-gas stream and at a wavelength of $0.9797 \AA$. A total of 900 images were collected with $0.2^{\circ}$ rotation range per image using a Pilatus $6 \mathrm{M}$ detector. The data were indexed and integrated using MOSFLM (Leslie \& Powell, 2007) via the iMosflm interface (v.7.1.1) (Battye et al., 2011). The crystal lattice is orthorhombic, and POINTLESS (Evans, 2006) suggests that the crystal is most likely to belong to either space group $P 2{ }_{1} 2_{1} 2$ or $P 2{ }_{1} 2_{1} 2_{1}$. For further analysis, the data were scaled and merged with AIMLESS (Evans \& Murshudov, 
2013 ) in space group $P 222$. The data-collection and processing statistics are summarized in Table 4.

\section{Results and discussion}

The rC1ORF123 protein with an N-terminal $6 \times$ His tag (rC1ORF123) was successfully overexpressed and purified to homogeneity using affinity chromatography (Ni-NTA) and size-exclusion chromatography (Superdex 75). rC1ORF123 migrated as a single protein band on SDS-PAGE with a molecular weight of approximately $20 \mathrm{kDa}$ (Fig. 1a) according

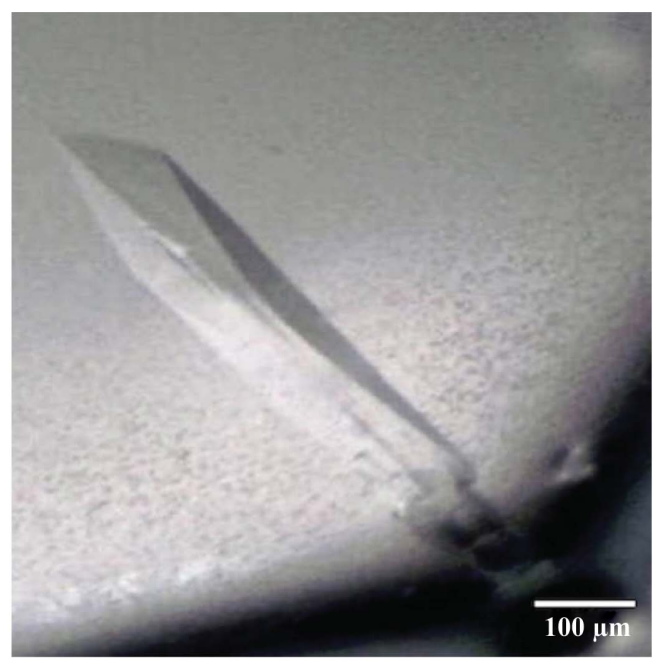

(a)

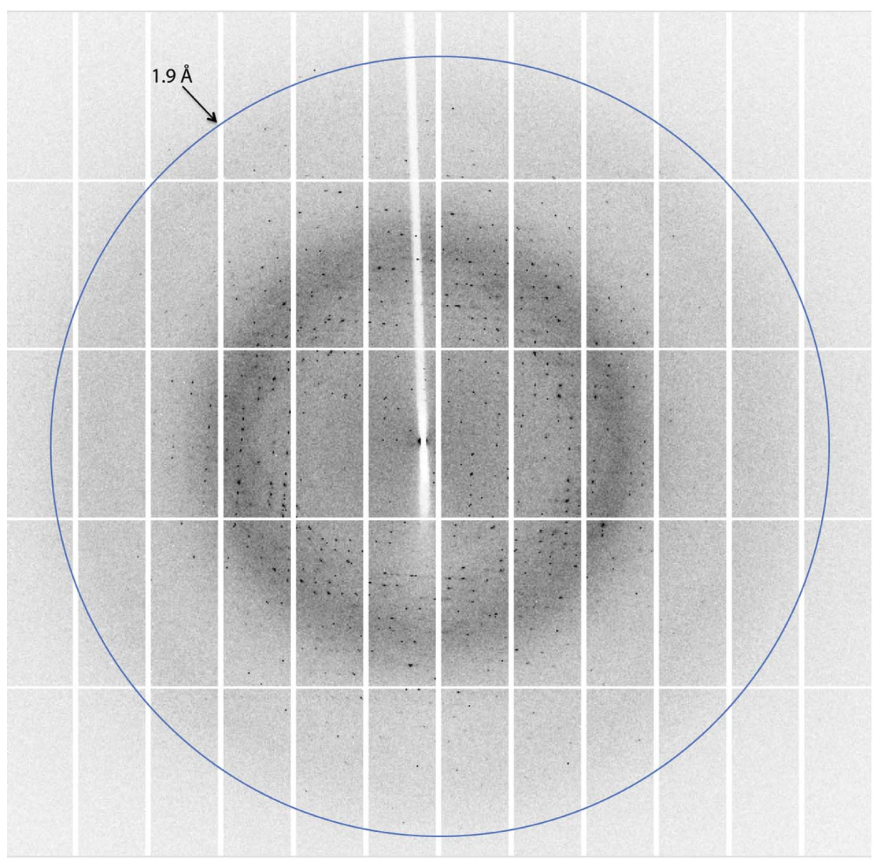

(b) to standard molecular-weight markers. Size-exclusion chromatography (SEC) showed the elution of a single peak containing rC1ORF123 with a retention time indicating that the molecular weight of the rC1ORF123 protein lies between those of myoglobin $(17 \mathrm{kDa})$ and ovalalbumin $(44 \mathrm{kDa})$ (Fig. 1b). The SEC calibration curve further indicates the molecular weight of rC1ORF123 to be $\sim 28 \mathrm{kDa}$ (Fig. 1c), which implies that the protein is most likely to exist as a monomer in solution. For protein validation, a Western blot was performed using anti-human C1ORF123 antibody against the rC1ORF123 protein. rC1ORF123 was positively detected by the antibody, which confirmed that the rC1ORF123 protein is similar to human C1ORF123 (Fig. 1d). To further verify the identity of rC1ORF123, the protein was validated by MALDITOF/TOF MS (Applied Biosystems/SCIEX). There were 62 peptides that matched $38 \%$ of the protein sequence of the human C1ORF123 protein (Fig. 3). Both the Western blot and the MALDI/TOF results confirmed that rC1ORF123 is identical to the human C1ORF123 protein.

The purified rC1ORF123 was concentrated to $8.0 \mathrm{mg} \mathrm{ml}^{-1}$ and used for crystallization screening. Initial crystal hits were obtained from several crystallization conditions that contained $0.2 \mathrm{M}$ magnesium or calcium ions, medium-size polyethylene glycol (PEG 3350 or PEG 8000) and buffers (sodium cacodylate, bis-tris or HEPES) with a pH in the range between 5.5 and 7.5. Crystals suitable for X-ray diffraction analysis were obtained after optimization from conditions that consisted of $0.2 \mathrm{M}$ magnesium chloride, $0.1 \mathrm{M}$ sodium citrate $\mathrm{pH} 6.5$, $20 \%(w / v)$ PEG 3350 (Fig. 2a). The crystals were flash-cooled in liquid nitrogen after the addition of an additional $20 \%$

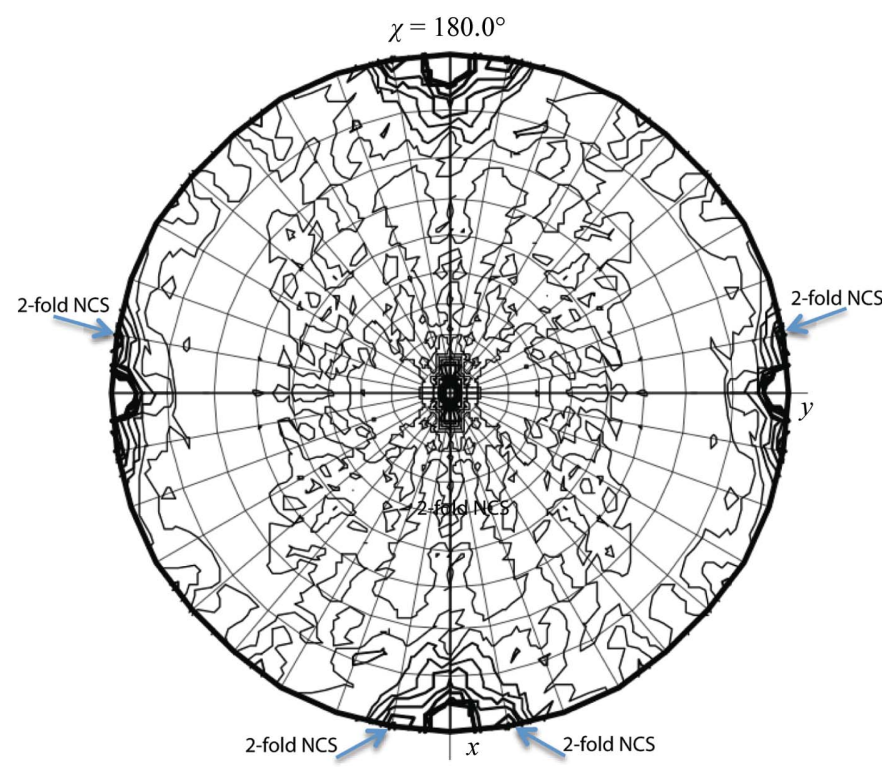

(c)

Figure 2

Protein crystal and diffraction images of recombinant human C1ORF123. (a) Crystal of rC1ORF123 grown using reservoir solution consisting of $0.1 M$ sodium citrate tribasic $\mathrm{pH}$ 6.5, 0.2 M magnesium chloride, 20\% PEG 3350. (b) A diffraction image of an rC1ORF123 protein crystal which diffracted to $1.9 \AA$ resolution on the I02 beamline at Diamond Light Source, UK. (c) Stereographic projection of the self-rotation function from rC1ORF123 data as calculated by MOLREP (Leslie \& Powell, 2007). The three perpendicular twofold crystallographic axes of point group 222 are present in the $\kappa=180^{\circ}$ section. The map also shows two pairs of noncrystallographic symmetry (NCS) twofold axes which are almost parallel to the crystallographic $x$ and $y$ axes. 


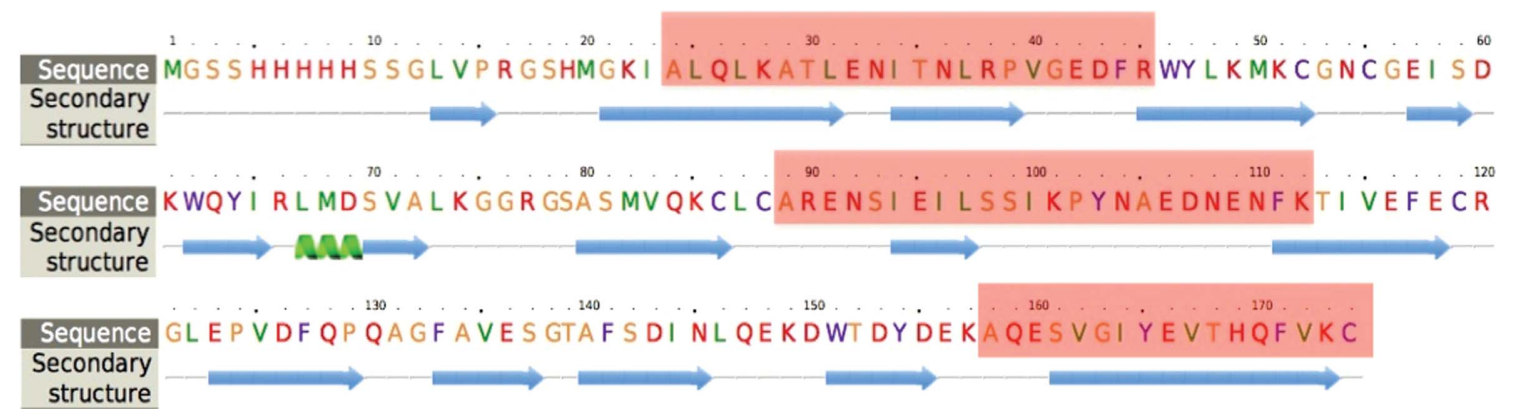

Figure 3

The secondary-structure prediction for rC1ORF123 determined by Phyre2 (Kelley et al., 2015) suggests that C1ORF123 contains $15 \beta$-strands, one $\alpha$-helix and 14 loop regions. Peptide sequences obtained using mass spectrometry (MALDI-TOF/TOF MS; Applied Biosystems/SCIEX) matching those of C1ORF123 are highlighted in red.

glycerol to the solution as a cryoprotectant. The best rC1ORF123 crystal, with dimensions of $\sim 400 \times 100 \times 50 \mu \mathrm{m}$, diffracted to $1.9 \AA$ resolution (Fig. $2 b$ ). Diffraction data were collected with $98.1 \%$ completeness on the I02 beamline at Diamond Light Source. The data were indexed and integrated using MOSFLM (Leslie \& Powell, 2007) and were scaled and merged with AIMLESS (Evans \& Murshudov, 2013). Indexing indicates that the crystal lattice is orthorhombic, with unit-cell parameters $a=59.32, b=65.35, c=95.05 \AA$. However, POINTLESS (Evans, 2006) suggests that the actual space group is either $P 2_{1} 2_{1} 2_{1}$ or $P 2_{1} 2_{1} 2$, and it has yet to be determined by further structural analysis. The crystallographic parameters and data-collection statistics are shown in Table 4. The calculated Matthews coefficient ( $V_{\mathrm{M}}$; Matthews, 1968) value of $2.28 \AA^{3} \mathrm{Da}^{-1}$ implies that the crystal consists of two rC1ORF123 molecules per asymmetric unit with an estimated solvent content of $46.1 \%$. The self-rotation function (Crowther, 1972) was calculated from the rC1ORF123 data using MOLREP (Vagin \& Teplyakov, 2010). The self-rotation function map shows three peaks in the $\kappa=180^{\circ}$ section that correspond to the three perpendicular crystallographic twofold axes of the point group (222; Fig. 2c). The map also shows two pairs of noncrystallographic symmetry (NCS) twofold axes which are almost parallel to the crystallographic $x$ and $y$ axes. The corresponding self-rotation function peaks are at approximately $\varphi= \pm 10^{\circ}$ and $\varphi= \pm 80^{\circ}$, suggesting that rC1ORF123 forms a dimer in the crystal. This is in good agreement with Holmes et al. (2006), who suggest that the $P$. falciparum homologue MAL13P1.257 might also form a weak dimer based on its crystal structure. Secondary-structure prediction using Phyre2 (Kelley et al., 2015) suggests that C1ORF123 forms $15 \beta$-strands (61\% sequence coverage) and one $\alpha$-helix ( $2 \%$ sequence coverage) and contains 14 loop regions (Fig. 3). This is similar to the P. falciparum homologue MAL13P1.257 (Holmes et al., 2006), which shares only 26\% sequence identity with C1ORF123. Currently, we are working towards the structure determination of rC1ORf123 by molecular replacement. Comparison of human rC1ORF123 with its homologue from a protozoan parasite along with analysis of their conserved regions and structural differences may help us to understand the biological function of the DUF866 protein family.

\section{Acknowledgements}

The authors would like to acknowledge the Ministry of Science, Technology and Innovation (MOSTI), Malaysia for financial support through the ScienceFund grant (02-01-02SF0993).

\section{References}

Batisse, J., Batisse, C., Budd, A., Böttcher, B. \& Hurt, E. (2009). J. Biol. Chem. 284, 34911-34917.

Battye, T. G. G., Kontogiannis, L., Johnson, O., Powell, H. R. \& Leslie, A. G. W. (2011). Acta Cryst. D67, 271-281.

Bringans, S. D., Kendrick, T., Lui, J. \& Lipscombe, R. J. (2008). Rapid Commun. Mass Spectrom. 22, 3450-3454.

Crowther, R. A. (1972). The Molecular Replacement Method, edited by M. G. Rossmann, pp. 173-178. New York: Gordon \& Breach.

Danielsen, J. M. R., Sylvestersen, K. B., Bekker-Jensen, S., Szklarczyk, D., Poulsen, J. W., Horn, H., Jensen, L. J., Mailand, N. \& Nielsen, M. L. (2011). Mol. Cell. Proteomics, 10, M110.003590.

Deng, R.-P., He, X., Guo, S.-J., Liu, W.-F., Tao, Y. \& Tao, S.-C. (2014). Proteomics, 14, 1020-1030.

Diamanti-Kandarakis, E. (2008). Expert Rev. Mol. Med. 10, e3.

Evans, P. (2006). Acta Cryst. D62, 72-82.

Evans, P. R. \& Murshudov, G. N. (2013). Acta Cryst. D69, 1204-1214.

Franceschini, A., Szklarczyk, D., Frankild, S., Kuhn, M., Simonovic, M., Roth, A., Lin, J., Minguez, P., Bork, P., von Mering, C. \& Jensen, L. J. (2013). Nucleic Acids Res. 41, D808-D815.

Gasteiger, E., Hoogland, C., Gattiker, A., Duvaud, S., Wilkins, M. R., Appel, R. D. \& Bairoch, A. (2005). The Proteomics Protocols Handbook, edited by J. M. Walker, pp. 571-607. Totowa: Humana Press.

Giot, L. et al. (2003). Science, 302, 1727-1736.

Holmes, M. A., Buckner, F. S., Van Voorhis, W. C., Mehlin, C., Boni, E., Earnest, T. N., DeTitta, G., Luft, J., Lauricella, A., Anderson, L., Kalyuzhniy, O., Zucker, F., Schoenfeld, L. W., Hol, W. G. J. \& Merritt, E. A. (2006). Acta Cryst. F62, 180-185.

Kelley, L. A., Mezulis, S., Yates, C. M., Wass, M. N. \& Sternberg, M. J. E. (2015). Nature Protoc. 10, 845-858.

Krogan, N. et al. (2006). Nature (London), 440, 637-643.

Leslie, A. G. W. \& Powell, H. R. (2007). Evolving Methods for Macromolecular Crystallography, edited by R. J. Read \& J. L. Sussman, pp. 41-51. Dordrecht: Springer.

Mahmood, T. \& Yang, P.-C. (2012). N. Am. J. Med. Sci. 4, 429-434.

Mate, S. E., Brown, K. J. \& Hoffman, E. P. (2011). Skelet. Muscle, 1 , 20.

Matthews, B. W. (1968). J. Mol. Biol. 33, 491-497.

Mohamed-Hussein, Z. A. \& Harun, S. (2009). Theor. Biol. Med. Model. 6, 18. 
Restelli, L., Codrea, M. C., Savoini, G., Ceciliani, F. \& Bendixen, E. (2014). J. Proteomics, 108, 295-305.

Schenk, L., Meinel, D., Strässer, K. \& Gerber, A. (2012). RNA, 18, 449-461.

Schubert, K. O., Föcking, M. \& Cotter, D. R. (2015). Schizophr. Res. 167, 64-72.

Selvarajan, S. \& Shanmughavel, P. (2014). Eur. J. Appl. Sci. Technol. 1, 43-49.
Stelzl, U. et al. (2005). Cell, 122, 957-968.

Vagin, A. \& Teplyakov, A. (2010). Acta Cryst. D66, 22-25.

Vazquez, J., Hall, S. C. \& Greco, M. A. (2009). Brain Res. 1298, 37-45.

Vinayagam, A., Stelzl, U., Foulle, R., Plassmann, S., Zenkner, M., Timm, J., Assmus, H. E., Andrade-Navarro, M. A. \& Wanker, E. E. (2011). Sci. Signal. 4, rs8.

Wearne, T. A., Mirzaei, M., Franklin, J. L., Goodchild, A. K., Haynes, P. A. \& Cornish, J. L. (2015). J. Proteome Res. 14, 397-410. 